\title{
A lysimeter study of nitrate leaching from grazed grassland as affected by a nitrification inhibitor, dicyandiamide, and relationships with ammonia oxidizing bacteria and archaea
}

\author{
H. J. Di ${ }^{1}$, K. C. Cameron ${ }^{1}$, J. P. $\mathrm{Shen}^{2}$, J. Z. $\mathrm{He}^{2}$ \& C. S. Winefield ${ }^{3}$ \\ ${ }^{1}$ Centre for Soil and Environmental Quality, PO Box 84, Lincoln University, Lincoln 7647, Canterbury, New Zealand, ${ }^{2}$ Research \\ Centre for Eco-Environmental Sciences, Chinese Academy of Sciences, 18 Shuangqing Road, Beijing 100085, China, and ${ }^{3}$ Faculty \\ of Agriculture and Life Sciences, PO Box 84, Lincoln University, Lincoln 7647, Canterbury, New Zealand
}

\begin{abstract}
Nitrate $\left(\mathrm{NO}_{3}{ }^{-}\right)$can contribute to surface water eutrophication and is deemed harmful to human health if present at high concentrations in the drinking water. In grazed grassland, most of the $\mathrm{NO}_{3}{ }^{-}-\mathrm{N}$ leaching occurs from animal urine- $\mathrm{N}$ returns. The objective of this study was to determine the effectiveness of a nitrification inhibitor, dicyandiamide (DCD), in decreasing $\mathrm{NO}_{3}{ }^{-}$leaching in three different soils from different regions of New Zealand under two different rainfall conditions (1260 mm and $2145 \mathrm{~mm}$ p.a.), and explore the relationships between $\mathrm{NO}_{3}{ }^{-}-\mathrm{N}$ leaching loss and ammonia oxidizing bacteria (AOB) and ammonia oxidizing archaea (AOA). The DCD nitrification inhibitor was found to be highly effective in decreasing $\mathrm{NO}_{3}{ }^{-}-\mathrm{N}$ leaching losses from all three soils under both rainfall conditions. Total $\mathrm{NO}_{3}{ }^{-}-\mathrm{N}$ leaching losses from the urine patch areas were decreased from $67.7-457.0 \mathrm{~kg}$ $\mathrm{NO}_{3}{ }^{-}-\mathrm{N} /$ ha to $29.7-257.4 \mathrm{~kg} \mathrm{NO}_{3}{ }^{-}-\mathrm{N} /$ ha by the DCD treatment, giving an average decrease of $59 \%$. The total $\mathrm{NO}_{3}{ }^{-}-\mathrm{N}$ leaching losses were not significantly affected by the two different rainfall treatments. The total $\mathrm{NO}_{3}{ }^{-}-\mathrm{N}$ leaching loss was significantly related to the amo $A$ gene copy numbers of the AOB DNA and to nitrification rate in the soil but not to that of the AOA. These results suggest that the DCD nitrification inhibitor is highly effective in decreasing $\mathrm{NO}_{3}{ }^{-}$leaching under these different soil and rainfall conditions and that the amount of $\mathrm{NO}_{3}{ }^{-} \mathrm{N}$ leached is mainly related to the growth of the AOB population in the nitrogen rich urine patch soils of grazed grassland.
\end{abstract}

Keywords: Nitrate leaching, nitrification inhibitor, ammonia oxidizing bacteria, ammonia oxidizing archaea, grazed grassland

\section{Introduction}

Nitrate $\left(\mathrm{NO}_{3}{ }^{-}\right)$can contribute to surface water eutrophication and is deemed harmful to human health if present at high concentrations in drinking water (WHO, 1984). A major source for $\mathrm{NO}_{3}{ }^{-}$in water bodies around the world is that leached from agricultural land. In grazed grassland where animals graze outdoor pastures, most of the $\mathrm{NO}_{3}{ }^{-} \mathrm{N}$ leached is from urine-nitrogen $(\mathrm{N})$ deposited by the animal during grazing (Scholefield et al., 1993; Ledgard et al., 1999; Di \& Cameron, 2002a). When animals graze pastures, between 70 and $90 \%$ of the $\mathrm{N}$ ingested is deposited on the pasture soil

Correspondence: H. J. Di. E-mail: hong.di@lincoln.ac.nz Received May 2009; accepted after revision August 2009 in the dung and urine and about $70 \%$ of this $\mathrm{N}$ is in the urine (Jarvis et al., 1995; Di \& Cameron, 2002a). The $\mathrm{N}$ loading rate under a dairy cow urine patch can be as high as $1000 \mathrm{~kg} \mathrm{~N} / \mathrm{ha}$. Most of the $\mathrm{N}$ in the urine is urea which, upon deposition in the soil, is quickly hydrolysed to ammonium $\left(\mathrm{NH}_{4}{ }^{+}\right)$and then oxidized to $\mathrm{NO}_{3}{ }^{-}$. The large amount of $\mathrm{NO}_{3}{ }^{-}$produced under the animal urine patches is prone to leaching when there is drainage, particularly during the cold winter period when pasture growth and $\mathrm{N}$ uptake is minimal, evapotranspiration is low and drainage is high (Di \& Cameron, 2002a).

A number of best management practices have been proposed to mitigate $\mathrm{NO}_{3}{ }^{-}$leaching from agricultural land (Addiscott, 1996; Di \& Cameron, 2002a). However, the mitigation of $\mathrm{NO}_{3}{ }^{-}$leaching from animal urine patches in grazed 
pastures is a major challenge because animal urine is deposited randomly in the grazed field at different times of year after each grazing rotation. A major development in recent years has been the use of nitrification inhibitors to treat grazed pasture soils to mitigate $\mathrm{NO}_{3}{ }^{-}$leaching (Di \& Cameron, 2002b, 2007). The nitrification inhibitor used in these studies, dicyandiamide (DCD), inhibits the first step of the nitrification process, that is the conversion from $\mathrm{NH}_{4}{ }^{+}$to hydroxylamine. This keeps the $\mathrm{N}$ in the $\mathrm{NH}_{4}{ }^{+}$form which can be held on the soil cation exchange complex and used for plant growth. DCD inhibits the nitrification process by deactivating the active site of the ammonia monooxygenase (AMO) enzyme in the ammonia oxidizing microbes. DCD is bacteriostatic and is not a biocide: it leaves no long-term residues in the soil (Amberger, 1989).

Despite the importance of the nitrification process in $\mathrm{N}$ cycling and in influencing $\mathrm{NO}_{3}{ }^{-}$leaching, it remains unclear if this process is driven by the ammonia oxidizing bacteria (AOB) or ammonia oxidizing archaea (AOA) or both. Recently, AOA has been shown to be present in different environments, including the ocean (Francis et al., 2005; Könneke et al., 2005; Wuchter et al., 2006), sediments (Schleper et al., 1997) and soils (Leininger et al., 2006; He et al., 2007; Chen et al., 2008; Shen et al., 2008), suggesting a potential role for AOA in nitrification in these ecosystems (Nicol \& Schleper, 2006; Prosser \& Nicol, 2008). Our latest research has shown that in the high-N-loading urine patch areas of grazed grassland, the nitrification rate is more closely related to the dynamics of the AOB populations (Di et al., 2009). However, the relationships between the dynamics of AOB and $\mathrm{AOA}$ and $\mathrm{NO}_{3}{ }^{-}$leaching losses are unknown. There is also insufficient information published on the effectiveness of nitrification inhibitors, such as DCD, in decreasing $\mathrm{NO}_{3}{ }^{-}$ leaching in different soil and environmental conditions, particularly under different rainfall conditions. It is not clear if different rainfall inputs may affect the transport and distribution of nitrogen and DCD in the soil thereby affecting the DCD effectiveness in decreasing $\mathrm{NO}_{3}{ }^{-}$leaching.

The objectives of this study were therefore to determine the effectiveness of the nitrification inhibitor, DCD, in reducing $\mathrm{NO}_{3}{ }^{-}$leaching in three grazed grassland soils under two rainfall conditions, and to explore relationships between $\mathrm{NO}_{3}{ }^{-}$leaching losses and $\mathrm{AOB}$ and AOA populations and nitrification rates.

\section{Materials and methods}

\section{Soils and pasture}

Three soils, from Canterbury (CT), the West Coast (WC) of the South Island, and Southland (SL) of New Zealand were used in this study (Table 1). The three soils differ significantly in their properties. The CT Lismore soil (NZ Classification: Pallic Orthic Brown Soil, Hewitt, 1998; USDA Soil Classification: Udic Haplustept loamy skeletal, Soil Survey Staff, 1998) is developed from gravelly glacial outwash covered with varying depths of loess. It has only a shallow layer of fine soil at the surface, below which the gravel content increases significantly, thus making this soil very free-draining. The WC Harihari soil (NZ classification: Mottled Fluvial Recent; USDA: Aquents) is a silt loam soil with a high silt content. The land at the site had been re-modelled to create 'humps' and 'hollows' to increase drainage, which is typical of local practise. The lysimeters were collected at the
Table 1 Properties of soils used for this study $(0-0.1 \mathrm{~m})$

\begin{tabular}{|c|c|c|c|}
\hline Location & $\begin{array}{c}\text { Canterbury } \\
\text { (CT) } 43^{\circ} 45^{\prime} 54^{\prime \prime} \mathrm{S} ; \\
171^{\circ} 41^{\prime} 25^{\prime \prime} \mathrm{E}\end{array}$ & $\begin{array}{c}\text { West Coast } \\
\text { (WC) } 42^{\circ} 42^{\prime} 12^{\prime \prime} \mathrm{S} \text {; } \\
171^{\circ} 26^{\prime} 43^{\prime \prime} \mathrm{E}\end{array}$ & $\begin{array}{l}\text { Southland } \\
\text { (SL) } 46^{\circ} 19^{\prime} 21^{\prime \prime} \text {; } \\
168^{\circ} 16^{\prime} 02^{\prime \prime} \mathrm{E}\end{array}$ \\
\hline Soil type & $\begin{array}{l}\text { Lismore stony } \\
\text { silt loam }\end{array}$ & $\begin{array}{l}\text { Harihari recent } \\
\text { silt loam }\end{array}$ & $\begin{array}{c}\text { Mataura recent } \\
\text { sandy loam }\end{array}$ \\
\hline \multicolumn{4}{|l|}{ Particle size (\%) } \\
\hline Sand & 10.5 & 4.2 & 69.1 \\
\hline Silt & 66.0 & 93.6 & 29.0 \\
\hline Clay & 23.5 & 2.2 & 1.9 \\
\hline $\mathrm{pH}\left(\mathrm{H}_{2} \mathrm{O}\right)$ & 5.9 & 5.4 & 5.6 \\
\hline Organic C (g/kg) & 36.5 & 68.8 & 62.6 \\
\hline Total N $(\mathrm{g} / \mathrm{kg})$ & 3.5 & 5.6 & 5.7 \\
\hline Olsen P (mg/kg) & 53.0 & 46.5 & 21.1 \\
\hline $\mathrm{CEC}\left(\mathrm{cmol}_{\mathrm{c}} / \mathrm{kg}\right)$ & 17.5 & 15.0 & 19.0 \\
\hline Exch. $\mathrm{Ca}^{2+}\left(\mathrm{cmol}_{\mathrm{c}} / \mathrm{kg}\right)$ & 10.3 & 5.0 & 6.7 \\
\hline Exch. $\mathrm{Mg}^{2+}\left(\mathrm{cmol}_{\mathrm{c}} / \mathrm{kg}\right)$ & 0.53 & 0.94 & 0.9 \\
\hline Exch. $\mathrm{K}^{+}\left(\mathrm{cmol}_{\mathrm{c}} / \mathrm{kg}\right)$ & 0.71 & 0.25 & 0.24 \\
\hline Base saturation $(\%)$ & 66.0 & 40.4 & 42.5 \\
\hline
\end{tabular}


'hump' or shoulder places. The SL Mataura soil is a recent sandy loam (NZ classification: Typic Fluvial Recent; USDA: Fluvents) developed in alluvium derived from schist and greywacke rock with a high sand content. The pasture on all three soils was a mixture of perennial ryegrass (Lolium perenne) and white clover (Trifolium repens) used for dairy grazing.

Large undisturbed soil monolith lysimeters ( $0.5 \mathrm{~m}$ diameter and $0.7 \mathrm{~m}$ deep) were collected from each of the three sites. The collection of the lysimeters involved placing a metal cylinder casing on the soil surface, digging around the casing, and gradually pushing the casing down by small increments (Cameron et al., 1992). Once the casing had reached the desired depth, the soil monolith was cut at the base with a cutting plate, secured on the lysimeter casing and lifted out of the collection site. The gap between the soil core and the casing was sealed using petroleum jelly to stop edge-flow effects. The lysimeters from the three sites were taken to and installed at a field lysimeter facility at Lincoln University which is about $20 \mathrm{~km}$ south of Christchurch on the east coast of the South Island. The lysimeters were installed on either side of a trench with the soil surface of the lysimeters at the same level as the surrounding field. The space outside the lysimeter casings was backfilled with soil to the same level as the surface of the lysimeters and the surrounding field. The lysimeters were thus exposed to the same climatic conditions as the soil and pasture in the surrounding field.

\section{Treatments}

For each soil type, there were two main treatments: urine; and urine plus soil treatment with the nitrification inhibitor DCD, and each treatment had four replicates. Fresh dairy cow urine was collected from lactating cows, analysed for total $\mathrm{N}$ concentrations and applied to the lysimeters at the equivalent rate of $1000 \mathrm{~kg} \mathrm{~N} /$ ha in May to simulate a typical dairy cow urine deposition (2 L of urine) (Di \& Cameron, 2002a). The DCD was dissolved in water and applied to the lysimeters at $10 \mathrm{~kg} / \mathrm{ha}$ after the urine application on the same day in May and again in August. The two DCD applications, one in the autumn and one in late winter/early spring followed standard recommendations in New Zealand to reduce nitrate leaching during this high drainage period. Urea fertilizer was applied to all the lysimeters at the annual rate of $200 \mathrm{~kg} \mathrm{~N} / \mathrm{ha}$, split into eight applications throughout the year, to simulate local practice of applying urea to the whole of grazed pasture including urine patch and non-urine patch areas.

Two rainfall conditions were created to test the influence of rainfall inputs on $\mathrm{NO}_{3}{ }^{-}$leaching. This was done by applying simulated rainfall to supplement natural rainfall to create $1100 \mathrm{~mm}$ and $2200 \mathrm{~mm}$ of annual rainfall. Simulated rainfall was applied using automated rainfall simulators. The amount of rainfall applied varied in different seasons with a greater amount applied during the summer to meet the higher water demand by plants because of greater evapotranspiration. For the $1100 \mathrm{~mm}$ condition, total rainfall during the winter was to reach the 75 th percentile of rainfall records during this period, and summer rainfall was to equal the total water input of rainfall plus irrigation normally applied in the Canterbury region where this research was conducted. The amount of water applied for the $2200 \mathrm{~mm}$ condition was simply to approximately double that of the $1100 \mathrm{~mm}$ water input in the different seasons to create two significantly different rainfall treatments. These two rainfall treatments would cover the range of rainfall conditions in the main dairy farming regions of New Zealand.

Pasture was cut to typical grazing heights and removed before the application of the treatments. Thereafter it and was cut at typical grazing intervals.

\section{Leachate collection and analysis}

Leachates from the lysimeters were collected as required (i.e. when the volume of drainage from the lysimeters was above $200 \mathrm{~mL}$ or weekly) for chemical analyses. The leachates were analysed for $\mathrm{NO}_{3}{ }^{-}$, nitrite $\left(\mathrm{NO}_{2}{ }^{-}\right)$, and $\mathrm{NH}_{4}{ }^{+}$concentrations by flow injection analysis (FIA) (Tecator Inc., Sweden).

\section{$A O B$ and $A O A$ populations and nitrification rate}

In order to explore the relationships between $\mathrm{NO}_{3}{ }^{-}$leaching, AOB and AOA populations and nitrification rate in the soil, a companion laboratory incubation study was conducted to quantify the dynamics of $\mathrm{AOB}$ and AOA in the soil and nitrification rate. Details of this study have been described by Di et al. (2009). Soils collected from the same areas as the lysimeters were treated with animal urine- $\mathrm{N}$ with and without DCD in a similar way to those described above and were incubated under simulated autumn-winter-spring conditions $\left(12^{\circ} \mathrm{C}\right)$ for about 3 months. Soil AOB and AOA populations were quantified using real-time PCR with primers targeting the amoA gene of the AOB and AOA DNA (Rotthauwe et al., 1997; Francis et al., 2005; Leininger et al., 2006; He et al., 2007). The amo $A$ gene encodes a subunit of the AMO enzyme responsible for the first step of the nitrification process, the conversion from ammonia to hydroxylamine. Nitrification rate was quantified by determining the amount of $\mathrm{NO}_{3}{ }^{-} \mathrm{N}$ produced during the incubation period by extracting soil samples with $2 \mathrm{~m} \mathrm{KCl}$ followed by standard flow injection analysis of $\mathrm{NO}_{3}{ }^{-}$concentrations in the extracts.

\section{Data analysis}

Annual $\mathrm{NO}_{3}{ }^{-} \mathrm{N}$ leaching losses were calculated on the basis of their concentrations in the leachate collected from each lysimeter and the volume of leachate. Average annual leaching losses were then calculated using values from the 
four replicates. Analysis of variance (ANOVA) of the data was performed using Genstat (11th Edition, Lawes Agricultural Trust). Standard errors (SE) of the mean were calculated and presented with the mean values.

\section{Results}

\section{Temperature and water inputs and outputs}

Daily average air temperature varied from a low of $0.8^{\circ} \mathrm{C}$ in June 2008 to a high of $34{ }^{\circ} \mathrm{C}$ in January 2009 (with an average $13.9{ }^{\circ} \mathrm{C}$ for the study period) (Figure 1a). Total annual water input, including rainfall and supplementary irrigation, reached $1260 \mathrm{~mm}$ for the lower rainfall target, slightly above the $1100 \mathrm{~mm}$ target because of a relatively wet winter (Figure 1b). Total water input in the higher rainfall regime reached $2145 \mathrm{~mm}$, just slightly under the target rainfall of

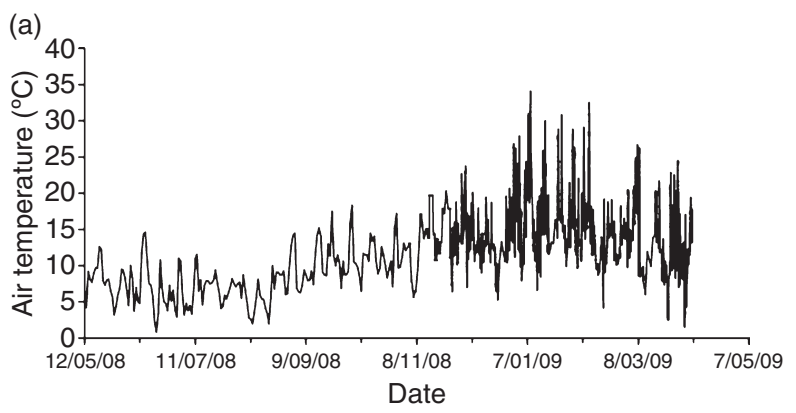

(b)

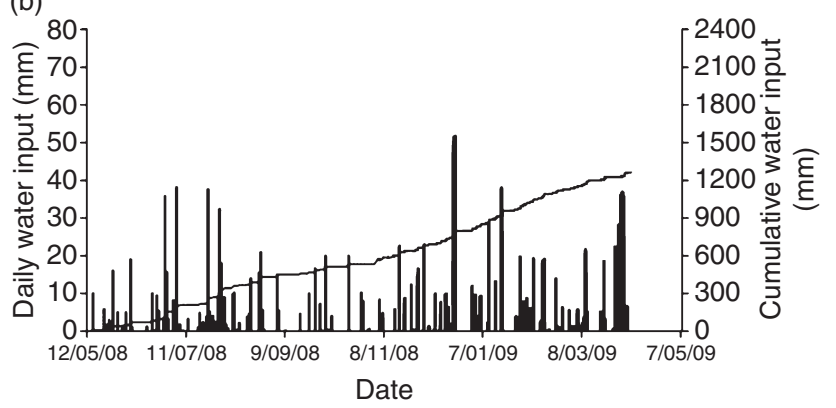

(c)

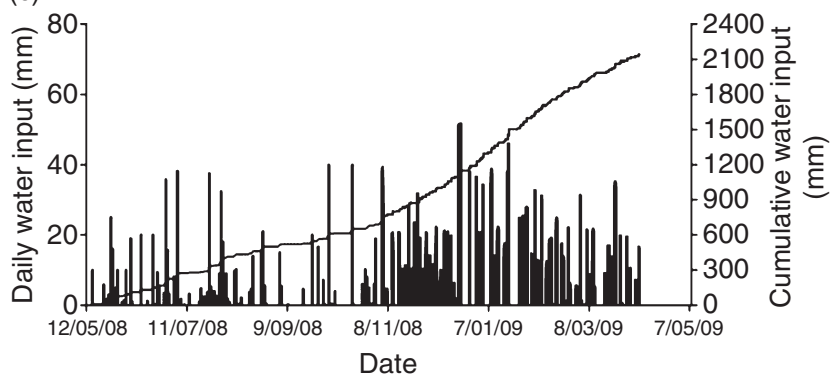

Figure 1 (a) Daily average air temperature; (b) daily and cumulative water inputs in the $1260 \mathrm{~mm}$ annual water input treatment; and (c) daily and cumulative water inputs in the $2145 \mathrm{~mm}$ annual water input treatment.
$2200 \mathrm{~mm}$ (Figure 1c). An average of $335 \mathrm{~mm}$ of drainage water was collected from the $1260 \mathrm{~mm}$ lysimeters and this is equivalent to about $27 \%$ of the annual water input. Under the $2145 \mathrm{~mm}$ rainfall treatment, an average of $683 \mathrm{~mm}$ of drainage was collected, equivalent to about $32 \%$ of the water input.

\section{Nitrate concentrations in the drainage water}

Under the $1260 \mathrm{~mm}$ rainfall treatment, nitrate-N concentration in the drainage water in the CT Lismore soil reached a peak of $263 \mathrm{mg} \mathrm{NO}{ }_{3}{ }^{-}-\mathrm{N} / \mathrm{L}$ in the urine treatment, and this was significantly $(P<0.05)$ reduced to $84 \mathrm{mg} \mathrm{NO}_{3}{ }^{-} \mathrm{N} / \mathrm{L}$ when DCD was applied (Figure 2a). In the SL Mataura soil, the $\mathrm{NO}_{3}{ }^{-}-\mathrm{N}$ concentration reached a peak of $240 \mathrm{mg}$ $\mathrm{NO}_{3}{ }^{-}-\mathrm{N} / \mathrm{L}$ in the urine treatment. This was significantly

(a)
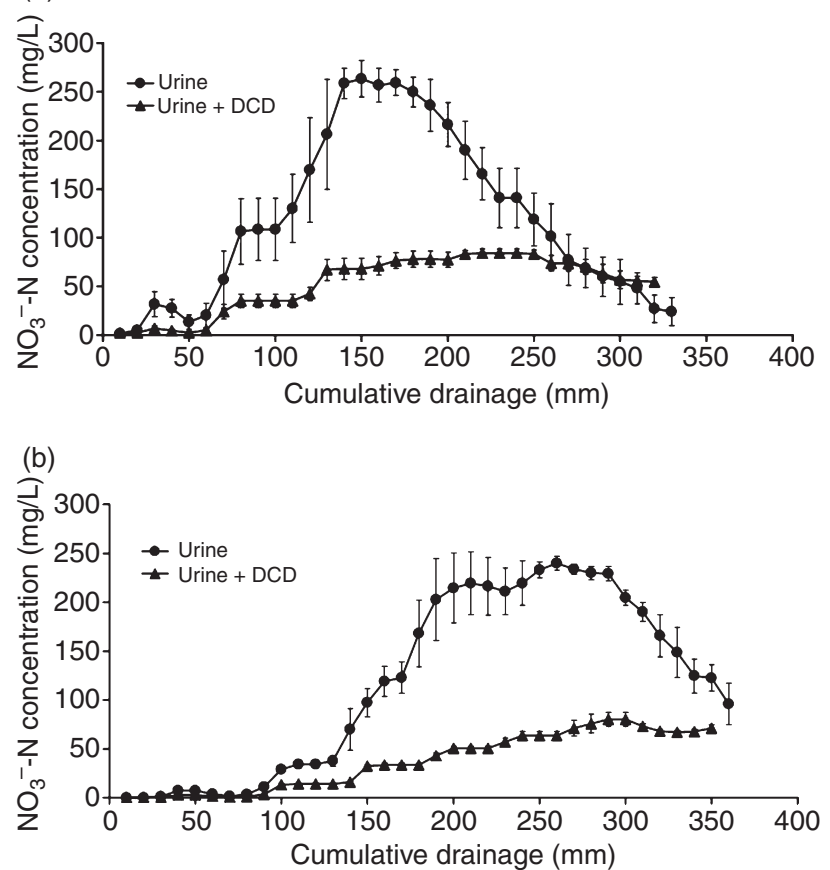

(c)

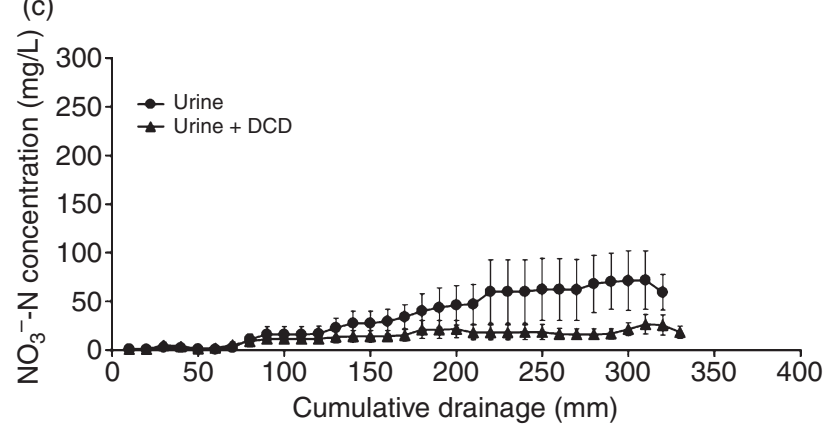

Figure 2 Nitrate-N concentrations $( \pm \mathrm{SE})$ in the drainage water from: (a) CT Lismore soil; (b) SL Matura soil; and (c) WC Harihari soil lysimeters under $1260 \mathrm{~mm}$ of water input. 
$(P<0.05)$ decreased to $80 \mathrm{mg} \quad \mathrm{NO}_{3}{ }^{-}-\mathrm{N} / \mathrm{L}$ with the application of DCD (Figure 2b). In the WC Harihari soil, the $\mathrm{NO}_{3}{ }^{-}-\mathrm{N}$ concentrations were considerably lower than those in the CT Lismore and SL Mataura soils, reaching a peak of 72 and $27 \mathrm{mg} \mathrm{NO}_{3}^{-}-\mathrm{N} / \mathrm{L}$ for urine and urine + DCD treatments, respectively (Figure 2c).

Under the $2145 \mathrm{~mm}$ rainfall treatment, the $\mathrm{NO}_{3}{ }^{-}-\mathrm{N}$ concentration in the drainage water in the SL Mataura soil reached a peak of $239 \mathrm{mg} \mathrm{NO}_{3}^{-}-\mathrm{N} / \mathrm{L}$ in the urine treatment (Figure 3a). This was significantly reduced to $93 \mathrm{mg}$ $\mathrm{NO}_{3}{ }^{-}-\mathrm{N} / \mathrm{L}$ when DCD was applied. In the WC Harihari soil, the $\mathrm{NO}_{3}{ }^{-}-\mathrm{N}$ concentrations in both the urine and urine + DCD treatments were significantly lower, reaching a peak of 52 and $29 \mathrm{mg} \mathrm{NO}{ }_{3}^{-}-\mathrm{N} / \mathrm{L}$ in the two treatments, respectively (Figure 3b). There was a blockage in some of the lysimeters in the CT Lismore lysimeters under the higher rainfall treatment which made the results unreliable (data not reported).

\section{Total nitrate-N leaching losses}

Under the $1260 \mathrm{~mm}$ rainfall treatment, total $\mathrm{NO}_{3}{ }^{-}-\mathrm{N}$ leaching losses in the urine treatment ranged from a low of $122.9 \mathrm{~kg} \mathrm{NO}{ }^{-}-\mathrm{N} / \mathrm{ha}$ in the WC Harihari soil to a high of $435.8 \mathrm{~kg} \mathrm{NO}_{3}{ }^{-} \mathrm{N} / \mathrm{ha}$ in the SL Mataura soil (Table 2). These were significantly decreased to between 35.8 and $176.5 \mathrm{~kg}$ $\mathrm{NO}_{3}{ }^{-}-\mathrm{N} /$ ha when DCD was applied $(P<0.05)$. These reductions in $\mathrm{NO}_{3}{ }^{-}$leaching losses by DCD were equivalent to $56-71 \%$.

Under the $2145 \mathrm{~mm}$ rainfall treatment, the total $\mathrm{NO}_{3}{ }^{-}-\mathrm{N}$ leaching losses in the urine treatment varied from $67.7 \mathrm{~kg}$ $\mathrm{NO}_{3}{ }^{-}-\mathrm{N} /$ ha in the WC Harihari soil to $457.0 \mathrm{~kg} \mathrm{NO}_{3}{ }^{-}-\mathrm{N} / \mathrm{ha}$ in the SL Mataura soil (Table 2). These were decreased to 29.7 and $257.4 \mathrm{~kg} \mathrm{NO}_{3}{ }^{-}-\mathrm{N} /$ ha with the application of DCD. These reductions in $\mathrm{NO}_{3}{ }^{-}$leaching because of DCD were equivalent to $44-56 \%$. The difference in the amount of
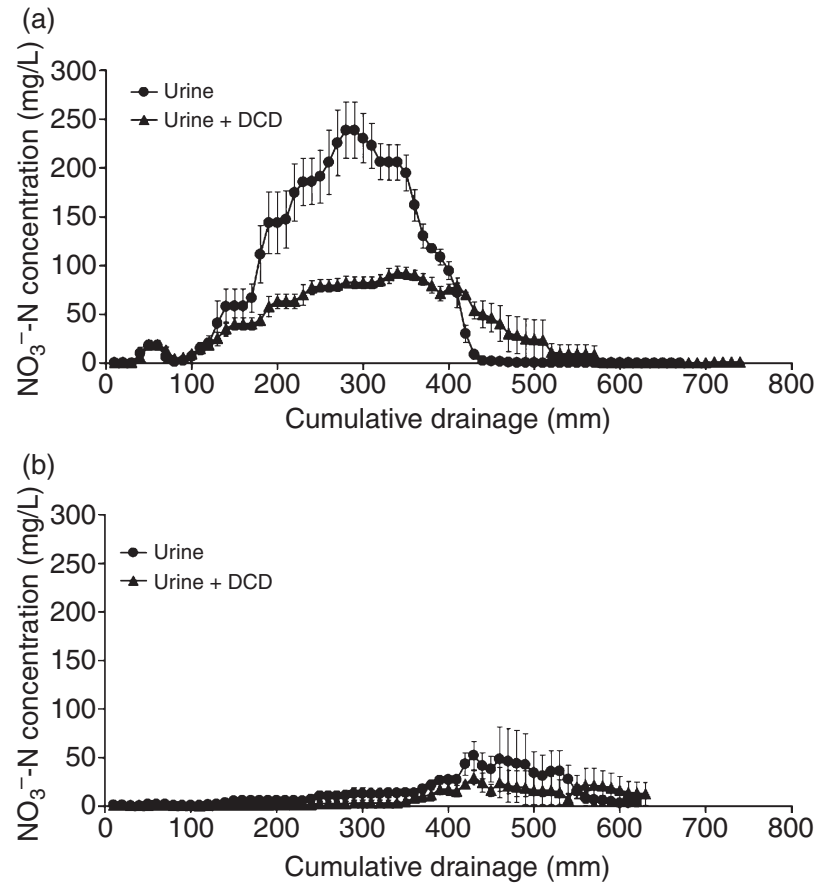

Figure 3 Nitrate-N concentration in the drainage water from: (a) SL Matura soil; and (b) WC Harihari soil lysimeters under $2145 \mathrm{~mm}$ of annual water input.

$\mathrm{NO}_{3}{ }^{-}-\mathrm{N}$ leached between the two rainfall treatments was not statistically significant $(P>0.05)$. The average reduction in $\mathrm{NO}_{3}{ }^{-} \mathrm{N}$ leaching loss by the DCD treatment under both rainfall treatments was $59 \%$.

\section{Dynamics of $A O B$ and $A O A$ populations}

Detailed results of the $\mathrm{AOB}$ and $\mathrm{AOA}$ populations are reported by Di et al. (2009). Briefly, both AOA and AOB

\begin{tabular}{|c|c|c|c|c|}
\hline Soil & $\begin{array}{l}\text { Rainfall } \\
\text { (mm p.a.) }\end{array}$ & Treatment & $\begin{array}{c}\mathrm{NO}_{3}{ }^{-}-\mathrm{N} \text { leached } \\
( \pm \mathrm{SE})(\mathrm{kg} / \mathrm{ha})\end{array}$ & $\begin{array}{l}\% \text { Reduction of } \\
\mathrm{NO}_{3}{ }^{-}-\mathrm{N} \text { leaching }\end{array}$ \\
\hline $\mathrm{CT}$ & 1260 & Urine & $399.0(27.3)$ & $-^{\mathrm{a}}$ \\
\hline $\mathrm{CT}$ & 1260 & Urine + DCD & $176.5(15.5)$ & 56 \\
\hline SL & 1260 & Urine & 435.8 (13.7) & - \\
\hline SL & 1260 & Urine + DCD & $142.2(0.9)$ & 67 \\
\hline WC & 1260 & Urine & $122.9(59.1)$ & - \\
\hline WC & 1260 & Urine + DCD & 35.8 (17.4) & 71 \\
\hline SL & 2145 & Urine & $457.0(53.4)$ & - \\
\hline SL & 2145 & Urine + DCD & $257.4(22.3)$ & 44 \\
\hline WC & 2145 & Urine & $67.7(25.1)$ & - \\
\hline WC & 2145 & Urine + DCD & 29.7 (11.5) & 56 \\
\hline \multicolumn{3}{|c|}{ SED for treatment } & 20.0 & \\
\hline \multicolumn{4}{|c|}{ Average reduction of $\mathrm{NO}_{3}{ }^{-}-\mathrm{N}$ leaching by DCD } & 59 \\
\hline
\end{tabular}

Table 2 Total $\mathrm{NO}_{3}{ }^{-}-\mathrm{N}$ leaching losses

${ }^{a}$ Not applicable. 
were detected in these soils in large numbers. The AOA population size was similar in the three soils, with amo $A$ gene copy numbers varying from $3.85 \times 10^{6}$ in the SL Mataura soil to $4.65 \times 10^{6}$ in the WC Harihari soil. However, the AOB population size varied significantly from $1.07 \times 10^{6}$ in the WC Harihari soil to $2.0 \times 10^{7}$ in the SL Mataura soil. The AOA to AOB ratio varied from 0.2 in the SL Mataura soil to 4.4 in the WC Harihari soil.

Following the application of dairy cow urine-N to the soils, the AOB population size grew 10.4-, 4.7- and 5.4-fold compared with the controls in the CT, WC and SL soils, respectively. The AOB growth was significantly inhibited by the application of the nitrification inhibitor, DCD. A significant relationship was found between the nitrification rate and the AOB population size. The AOA population, on the other hand, did not grow with the application of animal urine- $\mathrm{N}$, and was not related to the nitrification rate. The amo $A$ gene copy numbers of the AOB and AOA DNA were used here to determine the relationship between $\mathrm{NO}_{3}{ }^{-}-\mathrm{N}$ leaching losses and the abundance of AOB and AOA.

\section{Relationships between nitrate leaching and $A O B$ and $A O A$ populations}

The following significant relationship was found between total $\mathrm{NO}_{3}{ }^{-}-\mathrm{N}$ leaching loss from both rainfall treatments of the three soils and the AOB amo A gene copy numbers (Figure 4a):

$$
\begin{aligned}
y & =57.2+2.93 x \\
R^{2} & =0.51 ; P<0.01
\end{aligned}
$$

where $y$ is the total $\mathrm{NO}_{3}{ }^{-}-\mathrm{N}$ leaching loss $\left(\mathrm{kg} \mathrm{NO}_{3}{ }^{-}-\mathrm{N} / \mathrm{ha}\right)$, and $x$ is the AOB amo $A$ gene copy numbers (million copies per gram of soil). However, no relationship was found between the total $\mathrm{NO}_{3}{ }^{-}-\mathrm{N}$ leaching loss and the AOA populations (Figure 4b).

A significant relationship was also found between the total $\mathrm{NO}_{3}{ }^{-}-\mathrm{N}$ leaching loss from both rainfall treatments of the three soils and the nitrification rate as indicated by the amount of $\mathrm{NO}_{3}{ }^{-}-\mathrm{N}$ produced (Figure $4 \mathrm{c}$ ):

$$
\begin{aligned}
y & =-44.8+0.592 x \\
R^{2} & =0.67 ; P<0.01
\end{aligned}
$$

where $y$ is the total $\mathrm{NO}_{3}{ }^{-}-\mathrm{N}$ leaching loss $\left(\mathrm{kg} \mathrm{NO}_{3}{ }^{-} \mathrm{N} / \mathrm{ha}\right)$ and $x$ is the nitrate- $\mathrm{N}$ concentration in the soil $\left(\mathrm{mg} \mathrm{NO}_{3}{ }^{-}-\mathrm{N}\right.$ per $\mathrm{kg}$ soil) after 49 days of incubation when the AOB population reached a peak (Di et al., 2009).

\section{Discussion}

Results from this study show that the nitrification inhibitor, DCD, was highly effective in mitigating $\mathrm{NO}_{3}^{-}$leaching from all three soils under the two different rainfall treatments. The
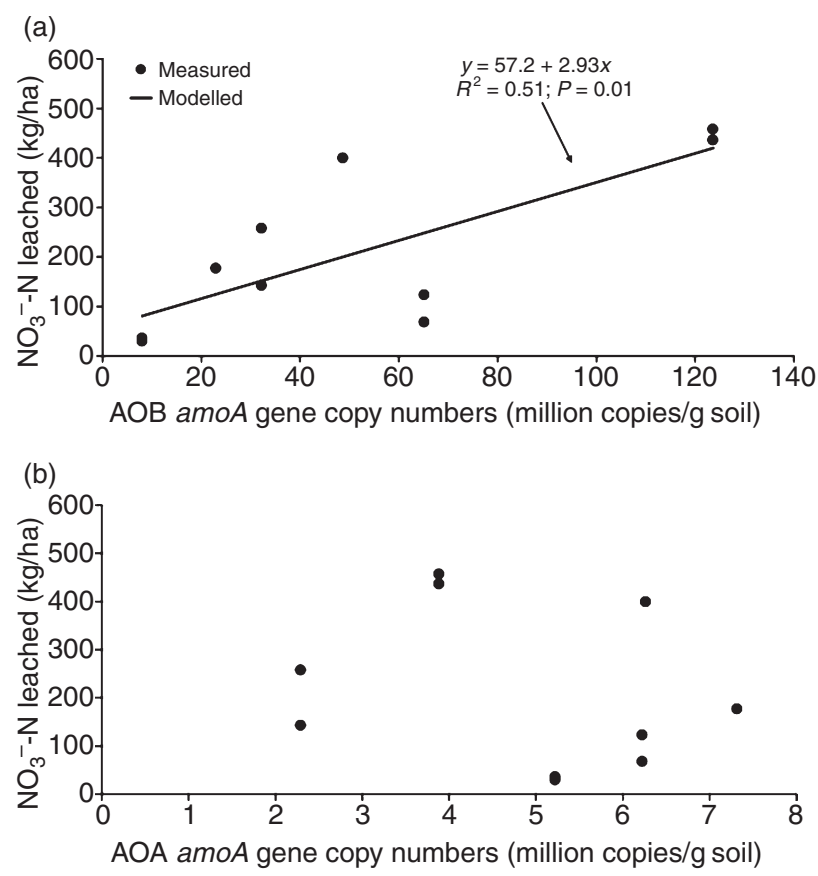

(c)

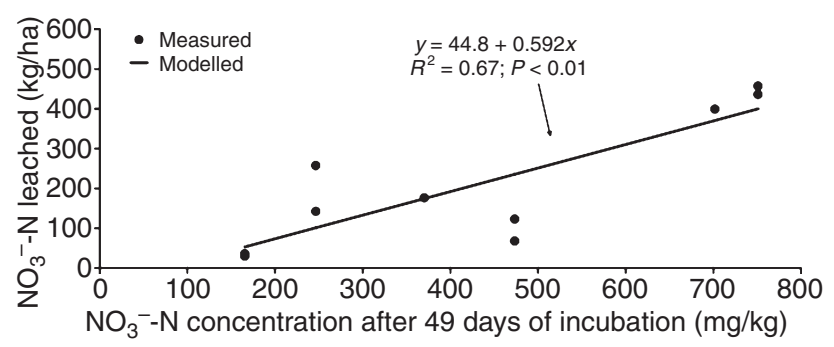

Figure 4 Relationships between total nitrate-N leaching losses from both rainfall treatments of the three soils and: (a) soil AOB DNA amo $A$ gene copy numbers; (b) soil AOA DNA amo $A$ gene copy numbers; and (c) amount of nitrate- $\mathrm{N}$ in the soil after 49 days when AOB populations peaked in soil in the companion incubation study.

$59 \%$ average reduction of $\mathrm{NO}_{3}{ }^{-}-\mathrm{N}$ leaching loss by DCD achieved in the three soils here are of a similar magnitude to those reported previously (e.g. Di \& Cameron, 2002b, 2007). The lower rainfall treatment $(1260 \mathrm{~mm})$ used in the present study is similar to the annual water inputs in the major dairy farming regions in the Waikato in the northern North Island, Southland in the southern South Island, and in Canterbury (rainfall + irrigation) in mid South Island of New Zealand. The higher rainfall treatment $(2145 \mathrm{~mm})$ is similar to those in the regions of Rotorua Lakes in Central North Island, and parts of the west coast of both Islands. These rainfalls are thus relevant to the major dairy farming regions across New Zealand.

Although different amounts of drainage $(335 \mathrm{~mm}$ vs. $683 \mathrm{~mm}$ ) were collected under the two rainfall treatments, there was no statistically significant difference between the 
amounts of $\mathrm{NO}_{3}{ }^{-} \mathrm{N}$ leached from the two rainfall treatments. This was partly because the $1260 \mathrm{~mm}$ water input was sufficient to leach most of the $\mathrm{NO}_{3}{ }^{-}$out of the soil profile, any additional water input would not result in significantly more $\mathrm{NO}_{3}{ }^{-}$being leached. This is shown by the very low $\mathrm{NO}_{3}{ }^{-}-\mathrm{N}$ concentrations in the drainage water at the later part of the graph in Figure 3a under the high rainfall condition. In addition, the wetter conditions of the higher rainfall treatment may have created an environment more conducive for denitrification, thus resulting in greater losses of nitrogen gases.

It is interesting that despite the large urine- $\mathrm{N}$ input at $1000 \mathrm{~kg} \mathrm{~N} /$ ha, the amount of $\mathrm{NO}_{3}{ }^{-}-\mathrm{N}$ leached from the $\mathrm{WC}$ Harihari was small, particularly in relation to the large $\mathrm{NO}_{3}{ }^{-}-\mathrm{N}$ leaching losses from the other two soils. This was probably related to the very high silt content $(93.6 \%)$ of the WC Harihari soil and thus slower drainage rate which may have resulted in the conversion of a large amount of the $\mathrm{NO}_{3}{ }^{-}$into nitrogen gases by denitrification. This may also be why the $\mathrm{NO}_{3}{ }^{-}-\mathrm{N}$ leaching loss under the higher rainfall treatment was less than that under the lower rainfall treatment in this soil; the higher rainfall treatment would have created a more favourable condition for denitrification. Further research is required to ascertain the mechanisms responsible for the small $\mathrm{NO}_{3}{ }^{-}$leaching loss from the WC Harihari soil.

Despite the critical importance of nitrification in the nitrogen cycle, our understanding of the role of the different ammonia oxidizers (e.g. AOB and AOA) in nitrification in different soil and environmental conditions and in affecting $\mathrm{NO}_{3}{ }^{-}$leaching is still limited. The recent discovery of the amo $A$ gene in the domain archaea and the detection of putative AOA in different ecosystems point to a potentially large role by AOA in nitrification (Francis et al., 2005; Könneke et al., 2005; Leininger et al., 2006; He et al., 2007; Prosser \& Nicol, 2008). Results from this study, however, show that the total $\mathrm{NO}_{3}{ }^{-}-\mathrm{N}$ leaching loss was significantly related to the abundance of the AOB population but not to the AOA population. This would support our finding reported separately that the nitrification rate was mainly related to the growth of AOB population rather than the AOA population in the urine patch soils with high nitrogen loads (Di et al., 2009). AOA may be particularly adapted to unfavourable or oligotrophic environments (Mahmood \& Prosser, 2006; Valentine, 2007; Shen et al., 2008; Di et al., 2009; Schauss et al., 2009). The high-N loading environment in the urine-treated soil therefore stimulated the growth of Nitrosopira species of the AOB but may be inhibitive for the AOA populations, thus limiting AOA growth and its role in nitrification and $\mathrm{NO}_{3}{ }^{-}$leaching at a low level (Di et al., 2009). The highly significant relationship between the total $\mathrm{NO}_{3}{ }^{-}-\mathrm{N}$ leaching loss and the nitrification rate (Figure 4c) and that between the nitrification rate and the AOB populations (Di et al., 2009) also provides a strong indirect link between the AOB population and $\mathrm{NO}_{3}{ }^{-}$leaching in grazed grassland with high nitrogen inputs. However, it must be noted that the abundance of AOB was only able to account for about $51 \%$ of the variation in $\mathrm{NO}_{3}{ }^{-}-\mathrm{N}$ leaching losses (as shown by the $R^{2}$ value). Other microbes and variables therefore also contribute to the variations in $\mathrm{NO}_{3}{ }^{-}-\mathrm{N}$ leaching, a topic that requires further research.

\section{Conclusions}

Results from this study a topic that demonstrate that the DCD nitrification inhibitor technology was highly effective in decreasing $\mathrm{NO}_{3}{ }^{-} \mathrm{N}$ leaching in three different soils under two contrasting rainfall treatments. The total $\mathrm{NO}_{3}{ }^{-}$ $\mathrm{N}$ leaching losses were not significantly affected by the amount of rainfall applied, partly because of the effect of rainfall on nitrogen losses from denitrification and partly because the amount of $\mathrm{NO}_{3}{ }^{-}-\mathrm{N}$ leached may have been limited by the amount of $\mathrm{NO}_{3}{ }^{-}$available for leaching rather than the amount of drainage. The significant relationship between the total $\mathrm{NO}_{3}{ }^{-} \mathrm{N}$ leaching loss and the abundance of the AOB population indicates the important role that the $\mathrm{AOB}$ population plays in nitrification and nitrogen cycling in the nitrogen rich urine patch soils of grazed grassland.

\section{Acknowledgements}

We thank the New Zealand Foundation for Research, Science and Technology (FRST), DairyNZ, Fonterra and Meat \& Wool New Zealand under the Pastoral21 research programme (Environment; C10X0603) for funding, Trevor Hendry, Steve Moore, Neil Smith, Nigel Beale, Carole Barlow, Jie Lei and Roger Atkinson for technical assistance, and Dr Ross Monaghan of AgResearch, Invermay, for collaboration.

\section{References}

Addiscott, T.M. 1996. Fertilizers and nitrate leaching. In: (eds R.E. Hester \& R.M. Harrison). Agricultural chemicals and the environment. Issues in Environmental Science and Technology, 5, pp. 1-26. The Royal Society of Chemistry, Cambridge.

Amberger, A. 1989. Research on dicyandiamide as a nitrification inhibitor and future outlook. Communication in Soil Science and Plant Analysis, 20, 1933-1955.

Cameron, K.C., Smith, N.P., McLay, C.D.A., Fraser, P.M., McPherson, R.J., Harrison, D.F. \& Harbottle, P. 1992. Lysimeters without edge-flow: an improved design and sampling procedure. Soil Science Society of America Journal, 56, 1625-1628.

Chen, X.P., Zhu, Y.G., Xia, Y., Shen, J.P. \& He, J.Z. 2008. Ammonia oxidizing archaea: important players in paddy rhizosphere soil? Environmental Microbiology, 10, 1978-1987.

Di, H.J. \& Cameron, K.C. 2002a. Nitrate leaching in temperate agroecosystems: sources, factors and mitigating strategies. Nutrient Cycling in Agroecosystems, 64, 237-256. 
Di, H.J. \& Cameron, K.C. 2002b. The use of a nitrification inhibitor, dicyandiamide (DCD), to reduce nitrate leaching and nitrous oxide emissions in a simulated grazed and irrigated grassland. Soil Use and Management, 18, 395-403.

Di, H.J. \& Cameron, K.C. 2007. Nitrate leaching losses and pasture yields as affected by different rates of animal urine nitrogen returns and application of a nitrification inhibitor - a lysimeter study. Nutrient Cycling in Agroecosystems, 79, 281-290.

Di, H.J., Cameron, K.C., Shen, J.P., Winefield, C.S., O'Callaghan, M., Bowatte, S. \& He, J.Z. 2009. Nitrification driven by bacteria and not by archaea in nitrogen rich grassland soils. Nature Geoscience, doi:10.1038/NGEO613.

Francis, C.A., Roberts, K.J., Beman, J.M., Santoro, A.E. \& Oakley, B.B. 2005. Ubiquity and diversity of ammonia-oxidizing archaea in water columns and sediments of the ocean. Proceedings of the National Academy of Sciences of the United States of America, 102, 14683-14688.

He, J.Z., Shen, J.P., Zhang, L.M., Zhu, Y.G., Zheng, Y.M., Xu, M.G. \& Di, H.J. 2007. Quantitative analyses of the abundance and composition of ammonia-oxidizing bacteria and ammonia-oxidizing archaea of a Chinese upland red soil under long-term fertilization practices. Environmental Microbiology, 9, 2364-2374.

Hewitt, A.E. 1998. New Zealand soil classification, 2nd edn. Manaaki Whenua Press, Lincoln, Canterbury, NZ.

Jarvis, S.C., Scholefield, D. \& Pain, B. 1995. Nitrogen cycling in grazing systems. In: Nitrogen fertilization in the environment (ed P.E. Bacon), pp. 381-419. Marcel Dekker, New York.

Könneke, M., Bernhard, A.E., de la Torre, J.R., Walker, C.B., Waterbury, J.B. \& Stahl, D.A. 2005. Isolation of an autotrophic ammonia-oxidizing marine archaeon. Nature, 437, 543-546.

Ledgard, S.F., Penno, J.W. \& Sprosen, M.S. 1999. Nitrogen inputs and losses from clover/grass pastures grazed by dairy cows, as affected by nitrogen fertilizer application. Journal of Agricultural Science, Cambridge, 132, 215-225.

Leininger, S., Urich, T., Schloter, M., Schwark, L., Qi, J., Nicol, G.W., Prosser, J.I., Schuster, S.C. \& Schleper, C. 2006. Archaea predominate among ammonia-oxidizing prokaryotes in soils. Nature, 442, 806-809.

Mahmood, S. \& Prosser, J.I. 2006. The influence of synthetic sheep urine on ammonia oxidizing bacterial communities in grassland soil. FEMS Microbiology and Ecology, 56, 444-454.
Nicol, G.W. \& Schleper, C. 2006. Ammonia-oxidising Crenarchaeota: important players in the nitrogen cycle? Trends in Microbiology, 14, 207-212.

Prosser, J.I. \& Nicol, G.W. 2008. Relative contributions of archaea and bacteria to aerobic ammonia oxidation in the environment. Environmental Microbiology, 10, 2931-2941.

Rotthauwe, J.H., Witzel, K.P. \& Liesack, W. 1997. The ammonia monooxygenase structural gene amoA as a functional marker: molecular fine-scale analysis of natural ammonia-oxidizing populations. Applied and Environmental Microbiology, 63, 47044712.

Schauss, K., Focks, A., Leininger, S., Kotzerke, A., Heuer, H., Thiele-Bruhn, S., Sharma, S., Wilke, B.M., Matthies, M., Smalla, K., Munch, J.C., Amelung, W., Kaupenjohann, M., Schloter, M. \& Schleper, C. 2009. Dynamics of functional relevance of ammoniaoxidizing archaea in two agricultural soils. Environmental Microbiology, 11, 446-456.

Schleper, C., Holben, W. \& Klenk, H.P. 1997. Recovery of crenarchaeotal ribosomal DNA sequences from freshwater-lake sediments. Applied and Environmental Microbiology, 63, 321-323.

Scholefield, D., Tyson, K.C., Garwood, E.A., Armstrong, A.C., Hawkins, J. \& Stone, A.C. 1993. Nitrate leaching from grazed grassland lysimeters: effects of fertilizer input, field drainage, age of sward, and patterns of weather. Journal of Soil Science, 44, 601-613.

Shen, J.P., Zhang, L.M., Zhu, Y.G., Zhang, J.B. \& He, J.Z. 2008. Abundance and composition of ammonia-oxidizing bacteria and ammonia-oxidizing archaea communities of an alkaline sandy loam. Environmental Microbiology, 10, 1601-1611.

Soil Survey Staff 1998. Keys to soil taxonomy, 8th edn. United States Department of Agriculture, Washington, DC.

Valentine, D.L. 2007. Adaptation to energy stress dictate the ecology and evolution of the Archaea. Nature Reviews Microbiology, 5, 316-323.

WHO 1984. Guidelines for drinking water quality. Vol 1. Recommendations. WHO, Geneva.

Wuchter, C., Abbas, B., Coolen, M.J.L., Herfort, L., van Bleijswijk, J., Timmers, P., Strous, M., Teira, E., Herndl, G.J., Middleburge, J.J., Schouten, S. \& Sinninghe Damste, J.S. 2006. Archaeal nitrification in the ocean. Proceedings of the National Academy of Science of the United States of America, 103, 12317-12322. 